\title{
"The solution of optimization problems in the economy by overlaying integer lattices: applied aspect"
}

\begin{tabular}{|c|c|}
\hline AUTHORS & Viktor Senchukov \\
\hline ARTICLE INFO & $\begin{array}{l}\text { Viktor Senchukov (2019). The solution of optimization problems in the economy } \\
\text { by overlaying integer lattices: applied aspect. Economics of Development, 18(1), } \\
\text { 44-55. doi:10.21511/ed.18(1).2019.05 }\end{array}$ \\
\hline DOI & http://dx.doi.org/10.21511/ed.18(1).2019.05 \\
\hline RELEASED ON & Monday, 10 June 2019 \\
\hline RECEIVED ON & Wednesday, 12 December 2018 \\
\hline ACCEPTED ON & Monday, 04 March 2019 \\
\hline LICENSE & $\begin{array}{l}(c) \text { EY } \\
\text { This work is licensed under a Creative Commons Attribution } 4.0 \text { International } \\
\text { License }\end{array}$ \\
\hline JOURNAL & "Economics of Development" \\
\hline ISSN PRINT & $1683-1942$ \\
\hline ISSN ONLINE & 2304-6155 \\
\hline PUBLISHER & LLC "Consulting Publishing Company "Business Perspectives" \\
\hline FOUNDER & Simon Kuznets Kharkiv National University of Economics \\
\hline
\end{tabular}

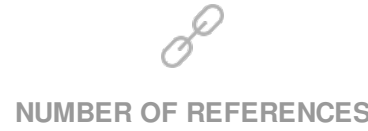

12

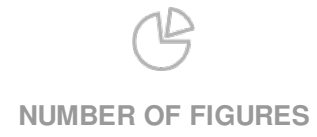

9
NUMBER OF TABLES

0

(C) The author(s) 2023. This publication is an open access article. 


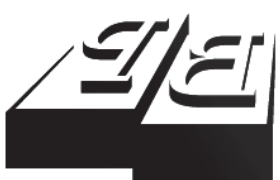

BUSINESS PERSPECTIVES

Publisher

LLC "CPC "Business Perspectives" Hryhorii Skovoroda lane, 10, Sumy, 40022, Ukraine www.businessperspectives.org

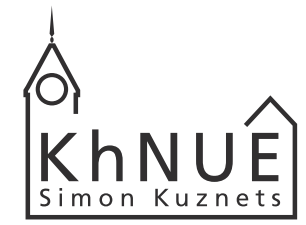

\section{S. KUZNETS KHNUE}

\section{Founder}

Simon Kuznets Kharkiv National University of Economics, Nauky avenue, 9-A, Kharkiv, 61166,

Ukraine

http://www.hneu.edu.ua/

Received on: $12^{\text {th }}$ of December, 2018 Accepted on: $04^{\text {th }}$ of March, 2019

\section{() Viktor Senchukov, 2019}

Viktor Senchukov, Ph.D. in Physical and Mathematical Sciences, Associate Professor of Department of Higher Mathematics and EconomicoMathematical Methods of Kharkiv National University of Economics named after Simon Kuznets, Ukraine.

\section{THE SOLUTION OF OPTIMIZATION PROBLEMS IN THE ECONOMY BY OVERLAYING INTEGER LATTICES: APPLIED ASPECT}

\begin{abstract}
The results of generalization of scientific approaches to the solution of modern economic optimization tasks have shown the need for a new vision of their solution based on the improvement of existing mathematical tools.

It is established that the peculiarities of the practical use of existing mathematical tools for solving economic optimization problems are caused by the problems of enterprise management in the presence of nonlinear processes in the economy, which also require consideration of the corresponding characteristics of nonlinear dynamic processes.

The approach to solving the problem of integer (discrete) programming associated with the difficulties that arise when applying precise methods (methods of separation and combinatorial methods) is proposed, namely: a fractional Gomorrhic algorithm - for solving entirely integer problems (by gradual "narrowing" areas of admissible solutions of the problem under consideration); the method of branches and borders - which involves replacing the complete overview of all plans by their partial directional over.
\end{abstract}

Illustrative examples of schemes of geometric programming, fractional-linear programming, nonlinear programming with a non-convex region, fractional-nonlinear programming with a nonconvex domain, and research on the optimum model of Cobb-Douglas model are given.

The advanced mathematical tools on the basis of the method of overlaying integer grids (OIG), which will solve problems of purely discrete, and not only integer optimization, as an individual case, are presented in the context of solving optimization tasks of an applied nature and are more effective at the expense of reducing the complexity and duration of their solving.

It is proved that appropriate analytical support should be used as an economic and mathematical tool at the stage of solving tasks of an economic nature, in particular optimization of the parameters of the processes of organization and preparation of production of new products of the enterprises of the real sector of the economy.

\section{Keywords}

JEL Classification economics and mathematical tools, optimization problem, parametric equations, target function
В. Ф. Сенчуков (Україна)

\section{РОЗВ'ЯЗАННЯ ОПТИМІЗАЦІЙНИХ ЗАДАЧ В ЕКОНОМІЦІ МЕТОДОМ НАКЛАДАННЯ ЦЛЛЧИСЛОВИХ СІТОК: ПРИКЛАДНИЙ АСПЕКТ}

\section{Анотація}

Результати узагальнення наукових підходів до вирішення сучасних економічних оптимізаційних задач засвідчили необхідність формування нового бачення щодо їх розв’язання на основі удосконалення існуючого математичного інструментарію.

Встановлено, що особливості практичного використання існуючого математичного інструментарію для розв'язання економічних оптимізаційних задач обумовлені проблемами управління підприємствами в умовах наявності нелінійних процесів в економіці, які вимагають також врахування відповідних характеристик нелінійних динамічних процесів.

Запропоновано підхід до вирішення проблеми цілочислового (дискретного) програмування, 
пов’язаної з труднощами, які виникають при застосуванні точних методів (методів відтинання та комбінаторних методів), а саме: дробовий алгоритм Гоморі - для розв'язання повністю цілочислових задач (шляхом поступового “звуження” області допустимих розв'язків розглядуваної задачі); метод гілок і меж - який передбачає заміну повного перебору усіх планів їх частковим напрямленим перебором.

Наведено ілюстративні приклади схем геометричного програмування, дробово-лінійного програмування, нелінійного програмування 3 неопуклою областю, дробово-нелінійного програмування 3 неопуклою областю, дослідження на оптимум моделі Кобба - Дугласа.

Представлено удосконалений математичний інструментарій на основі методу накладання цілочислових сіток (НЦС), який дозволить розв'язувати задачі суто дискретної, а не тільки цілочислової оптимізації як окремого випадку, в контексті вирішення оптимізаційних завдань прикладного характеру і $€$ більш ефективним за рахунок зменшення трудомісткості та терміну їх розв'язування.

Доведено, що відповідне аналітичне забезпечення доцільно використовувати у якості економіко-математичного інструментарію на етапі вирішення завдань економічного характеру, зокрема оптимізації параметрів процесів організації і підготовки виробництва нових виробів підприємств реального сектору економіки.

Ключові слова

Класифікація JEL економіко-математичний інструментарій, оптимізаційна задача, параметричні рівняння, цільова функція

C61

\section{ВСТУП}

Кардинальні зміни параметрів функціонування суб'єктів економіки в сучасних умовах глобалізаційного розвитку вимагають від науковців і фахівців практичного сектору нових підходів до аналізу ефективності взаємозв'язків між всіма підсистемами і учасниками економічних відносин. Вирішення існуючої проблеми отримання адекватних висновків за результатами оцінки динаміки економічних процесів вимагає від дослідників необхідності розвитку теоретичних положень, забезпечення використання ефективних методів дослідження, впровадження удосконалених методичних підходів, а також використання відповідного економіко-математичного інструментарію в аспекті оптимізації визначених параметрів. Це також свідчить про їх велике практичне значення, що обумовлено виникненням сучасної потреби щодо отримання відповідей в форматі кількісних і якісних параметрів показників на етапі пошуку рішень і завдань розвитку суб'єктів господарювання з врахуванням змін як внутрішнього, так і зовнішнього середовища.

Актуальність роботи полягає в необхідності формування нових підходів до вирішення сучасних економічних оптимізаційних задач на основі удосконалення існуючого математичного інструментарію.

Серед дослідників економіко-математичного профілю і фахівців практиків широко відомі класичні задачі. Так задача про рюкзак (задача комбінаторної оптимізації) дозволяє отримати певний сценарій досягнення максимізації сумарної вартості корисного вмісту речей з врахуванням обов'язкового виконання іншої умови-параметру - обмеження й не перевищення максимальної припустимої маси. Консолідовані алгоритми в межах даної задачі в практичному секторі економіки дозволяють фахівцям 3 управління підприємством вирішити багато інших економічних завдань, що певною мірою сформовані тими чи іншими проблемами. 3 точки зору наявності ії у якості певної під задачі в структурі більш загальних задач, підтверджує значущість такого математичного інструментарію для широкого напряму наукових досліджень.

Відома задача оптимального розкрою матеріалів має практичний приклад необхідних алгоритмів на етапі прийняття організаційних рішень менеджерами в умовах організації і управління промислових підприємств. При цьому для прийняття вірного рішення є обов'язковим врахування багатьох факторів -одиничний (серійний або масовий) тип виробництва, конфігурація заготовок (матеріалу), обсяг виробництва продукції та ін. Розв’язання такої задачі в умовах функціонування конкретного промислового підприємства щодо випуску певного виду продукції дозволяє забезпечити умови отримання достатнього прибутку і подальшого його ефективного розвитку.

Задача комівояжера чітко демонструє можливості зокрема сучасним менеджерам 3 логістики щодо використання алгоритмів (математичного інструментарію) у знаходженні найвигіднішого маршруту (за 
пеними критеріями - найкоротший, найдешевший, сукупний критерій та ін.) однієї доставки певної партії товару, що проходить через обов'язкові пункти доставки (міста, логістичні склади). При цьому обов’язковою умовою $є$ наявність шаблонів певних параметрів (вартісних, технічних), які задано заздалегідь. Для дослідників подібні алгоритми дозволяють здійснювати апробацію новітніх управлінських підходів, заснованих на евристичному скороченні повного перебору існуючих (сценаріїв) варіантів досягнення умовного результату.

Широке застосування в практичному секторі економіки мають узагальнені підходи до управління окремими виробничими процесами на підприємствами, в межах задачі з постійними елементами витрат (задача планування виробничої лінії).

Задача про призначення також $є$ однією з базових задач комбінаторної оптимізації і з іншого боку належить до задач лінійного програмування. Практична цінність ії з точки зору можливостей вирішення завдань економічного характеру полягає у розгляді певної транспортної задачі, яку доцільно розглядати у якості алгоритму визначення параметрів потоку мінімальної вартості за певних умов того, який агент вирішує виробничу ситуацію.

Сучасні вимоги до вирішення проблем оптимізації підтверджують, що висвітлені вище інструменти потребують удосконалення на основі методу накладання цілочислових сіток (НЦС). Такий підхід дозволяє розв'язувати задачі суто дискретної, а не тільки цілочислової оптимізації як окремого випадку.

Запропоновані оригінальні конструктивні засоби оптимізації розроблені під впливом і у світлі ідей, які привели до створення Рвачовим (1982) теорії R-функцій [8]. За допомогою цих функцій була розв'язана обернена задача аналітичної геометрії: опис одним аналітичним виразом рівняння, відповідне заданому геометричному об'єкту (лінії, кресленню). Аналогічна задача постає стосовно аналітичного опису дискретної, зокрема цілочислової множини точок двовимірного простору (площини) та тривимірного простору, і загалом - багатовимірного простору, що можна вважати результатом подальших досліджень. Вперше впровадження цілочислових сіток у задачі дискретного програмування показано в роботі автора [9].

Метою дослідження є уніфікація відомих методів, яка не потребує розв'язання послабленої задачі математичного програмування, тобто без урахування дискретності змінних. Другим аспектом уніфікації $\epsilon$ забезпечення можливості для будь-якої цільової функції, обмеженої в довільній області допустимих планів, знайти екстремальне значення.

Пошук літературних джерел стосовно ознайомлення з результатами наукового доробку фахівців 3 досліджуваної проблематики дозволяє зробити висновок про відсутність грунтовних наукових публікацій, присвячених її вирішенню.

Реалізація запропонованого в роботі підходу до розв'язання задач цілочислового (дискретного) програмування потребує деяких попередніх відомостей.

Відомість 1. Опис змісту використаних теоретичних положень, понять та процедур. Одновимірні, двовимірні та тривимірні числові бруси: основні поняття та побудова

Під нумерацією [3] розуміють відображення певної підмножини натуральних чисел $N$ на клас досліджуваних конструктивних об’єктів (формул, слів, матриць і таке інше). У пропонованій роботі розглядаються відображення множини $N$ в (на) множину $Z^{m}$.

Підмножину нумерації, яка задовольняє певні умови, називають цілочисловою сіткою. 
Побудова цілочислових сіток (далі - просто сіток) здійснюється в два етапи [10]:

1) вибір правил - схеми нумерації, - за якими здійснюється присвоєння натуральних номерів точкам цілочислового простору;

2) аналітичний опис - установлення залежності - цілочислових координат точки від приписаного за схемою номера та відновлення за координатами номера цілої точки.

Існує безліч схем нумерації цілих точок (ЦТ) прямої. Виберемо одну з них (Рисунок 1). Починати нумерацію можна з будь-якої точки числової осі. Візьмемо в якості початкової точку $O$.

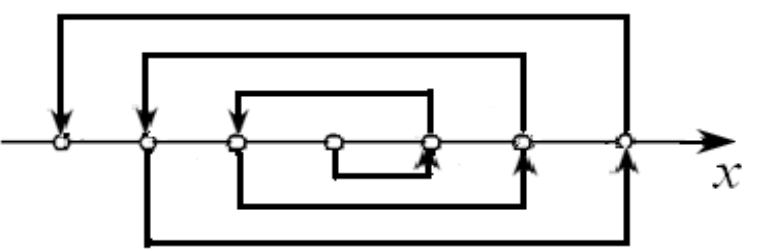

$\begin{array}{cccccccc}7 & 5 & 3 & 1 & 2 & 4 & 6 & \\ -3 & -2 & -1 & 0 & 1 & 2 & 3 & x\end{array}$

Рисунок 1. Схема нумерації $Z$
Послідовність переходу від точки до точки показана стрілочками (від початку відліку).

Номери точок нанесено над віссю Ox. Аналізуючи вибрану схему, приходимо до висновку, що точка х і іï номер n пов'язані бієктивним співвідношенням:

$n \leftrightarrow x \Leftrightarrow n \leftrightarrow(-1)^{n} \cdot[n / 2]$

Вибір схеми нумерації (можливому варіанту на етапі прийняття рішень) залежить від того, для розв’язання якої прикладної задачі (специфіки економічних завдань) вона використовується. Безумовно, відповідна сітка повинна задовольняти умови поставленої задачі, сприяла більш ефективній, за швидкістю, чисельній реалізації. Від вибору схеми нумерації суттєво залежить об’єм обчислювальної роботи, особливо, коли йдеться про багатовимірні сітки.

Здійснену нумерацію цілочислової осі $O x$ (див. Рисунок 1 ) використаємо для нумерації ЦТ двовимірного простору. Для цього виберемо декартову координатну площину $x O y$, вісь абсцис якої суміщена зі занумерованою віссю. Далі виберемо на $O x$ цілочисловий відрізок [-a, a], який міститиме (2a+1)-у точку. На площині $x O y$ розглянемо вертикальну сму-гу шириною $w=2 a+1, a=3$. Щоб отримати наступний шар точок як деяку підмножину $Z^{2}$, від точки з найбільшим номером на $O x$ (Рисунок 2) переходимо до точки на $O y$ із ординатою $y=1$, і приписуємо їй черговий номер. Якщо $a=3$, то на $O x$ це точка $x=-3$ з номером $n=7$, а на прямій $y=1$ отримуємо точку з номером $n=8$. Процес продовжується наданням ординаті значень $y=2,3, \ldots$ до тих пір поки цілочисловим прямокутником не буде охоплюватись область, на якій розглядається задача оптимізації. Множину точок, яка відповідає кожному фіксованому значенню $y$, називають шаром точок.

На Рисунку 2 стрілочками показано послідовність нумерації точок вертикальної смуги. Чітко у процесі нумерації простежуються два етапи:

1) за схемою нумерації обведення точок шару;

2) побудова наступного шару переходом (по похилій) до чергового значення ординати.

Аналогічно будується довільна кількість шарів і з від’ємними ординатами. 


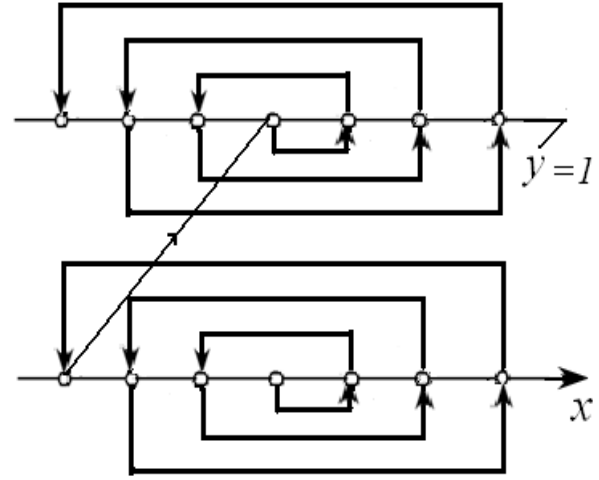

у даному викладі в основу побудови плоских і $m$-вимірних сіток $(m>2)$ покладена нумерація за схемою Серпінського (1961) [12], яка описується формулами [11]:

$$
\begin{aligned}
& x=(-1)^{\mathrm{b}-1}([\mathrm{~b} / 2]+\min (0, \mathrm{n}-\mathrm{B})), \\
& y=(-1)^{\mathrm{b}}([\mathrm{b} / 2]-\max (0, \mathrm{n}-\mathrm{B})),
\end{aligned}
$$

де $x, y$ - координати цілих точок в $Z^{2}$,

$$
b=[\sqrt{n-1}]+1, B=(b-1) b+1 .
$$

Рисунок 2. Схема побудови шарів цілих точок

Множина цілих точок у просторі $Z^{3}$, яка включає в себе цілі точки внутрішності і повної поверхні прямокутного паралелепіпеда називається цілочисловим брусом (далі - брусом). Окремим випадком бруса $\epsilon$ цілочисловий куб. Паралельним перенесенням його можна розташувати в усіх чи декількох октантах.

Тривимірний цілочисловий брус позначимо через $\operatorname{Bar}(k, h)$, де параметр $k$ - номер квадрата, який покладено в його основу згідно з (1); $h$ - висота бруса як кількість шарів ЦТ по вертикалі. Бруси 3 невід’ємними аплікатами $z(n)$ описуються співвідношенням:

$$
z(n)=\left[(n-1) / N_{2}\right]=\left[(n-1) /(2 k+1)^{2}\right], n=1,2,3, \ldots, h \cdot N_{2},
$$

де $N_{2}=(2 k+1)^{2}-$ кількість точок основи вибраного бруса.

Якщо $n \in\left[(h-1) \cdot(2 k+1)^{2}, h \cdot(2 k+1)^{2}\right]$, то за таких умов для $h=1,2,3, \ldots$ матимемо, відповідно, $z=h-1=0,1,2, \ldots$.

Зсувом брусу, а разі потреби, з невід’ємними аплікатами у від’ємному напрямі променя-півосі $O z$ отримаємо бруси тільки з від’ємними або з від’ємними і додатними аплікатами.

На Рисунку 3 зображено брус з параметрами $k=1, h=4$. Згідно з (2) такий брус охоплює всього 36 цілих точок: кожен шар містить 9 точок, а кількість шарів дорівнює 4.

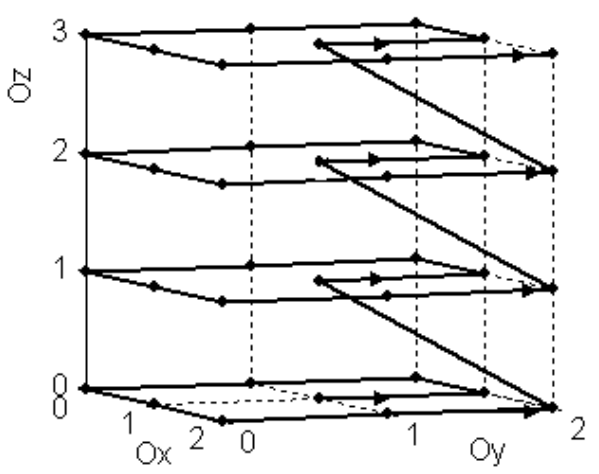

Порядок присвоєння номерів цілим точкам простежується за стрілочками, починаючи з центра шару на площині $x O y$.

У процесі нумерації чітко простежуються два етапи: обведення точок кожного шару, підіймання на одиницю (по похилій) до чергового шару.

Брус побудований засобами пакету прикладних програм MatLab [7].

Одновимірний брус (1-брус) - цілочислову сітку на прямій

Рисунок 3. Зображення бруса $\operatorname{Bar}(1,4)$ - слід розглядати як підмножину $Z$. 
Двовимірний брус (2-брус) в $Z^{3}$ отримуємо конкатенацією (зчепленням) одновимірних брусів (див. Рисунок 2), а зчеплення кількох таких брусів породжує тривимірний брус (3-брус) в $Z^{3}$.

Відомість 2. Побудова багатовимірних ( $m$-вимірних, $m>3$ ) брусів

Без принципових змін описаний конструктивний підхід до побудови сіток на прямій, на площині, у просторі $Z^{3}$ узагальнюється на простори більшої вимірності. Брусом цілих точок у $Z^{m} \in$ конкатенація брусів із $Z^{m-1}$. Основні етапи побудови: обведення точок вихідного $(m-1)$-бруса; конкатенація необхідної (заданої) кількості вихідних брусів.

Позначення $m$-бруса міститиме (m-1) параметрів: $\operatorname{Bar}\left(k, s_{3}, s_{4}, \ldots, s_{m}\right)$, де $s_{i} 3 \leq i \leq m$, якими, крім першого, визначається кількість операндів (шарів) зчеплення. Звичайно за основу 3-бруса беруть нумерацію за координатними функціями (1), які описують 2-брус.

Кількість точок шарів виміру $2,3, \ldots, m$, підраховується за формулами:

$$
\begin{aligned}
& N_{2}=(2 k+1)^{2}, n_{2}=\overline{1, N_{2}} \\
& N_{i}=N_{i-1} \cdot s_{i}, n_{i}=\overline{1, N_{i}}, i=3,4, \ldots, m .
\end{aligned}
$$

Якщо взяти, наприклад, $k=1, s_{3}=2, s_{4}=2, s_{5}=3$, то отримаємо п’ятивимірний брус $\operatorname{Bar}(1,2,2,3)$. В його основі лежить 1-квадрат, тривимірний брус має два шари, 4-брус являє собою конкатенацію двох тривимірних брусів, а зчеплення трьох таких брусів дає п'ятивимірний брус з трьох шарів. На такому брусі була проведена апробація алгоритму побудови п'ятивимірних сіток. Ми живемо в тривимірному світі, тому нам важко уявити собі світ іншого виміру.

Оскільки алгоритм побудови $m$-брусів спирається на використання відповідних формул, то створення програмного забезпечення на ЕОМ для реалізації побудови не викликає труднощів. Дане програмне забезпечення можна використовувати у якості економіко-математичного інструментарію для вирішення завдань економічного характеру, зокрема оптимізації параметрів процесів організації і підготовки виробництва нових виробів на підприємствах реального сектору економіки.

Відомість 3. Опис методу накладання цілочислової сітки та ілюстративні приклади застосування

Запропонований в роботі підхід до цілочислової оптимізації передбачає можливість не залучати попередньо послаблену задачу цілочислового програмування (ЗЦП).

Застосування відомих точних методів до розв'язання ЗЦП, а саме: метод відтинання в дробовому алгоритмі Гоморі і гілкування в комбінаторних методах $[4 ; 5]$ потребує здійснювати перехід до наступної цілої точки, а потім діагностувати отриманий допустимий план на оптимальність. Це тягне за собою потребу кожного разу (для кожної цілої точки) розв’язувати окрему задачу, що ускладнює пошук оптимального плану. У противагу названим методам пропонується аналітичний опис відразу усіх цілих точок області допустимих значень. Такий підхід до розв'язання ЗЦП названо методом накладання цілочислової сітки (НЦС).

Він реалізується за три кроки:

- $\quad$ опис множини цілих точок $D^{c}$, які охоплює задана область допустимих значень $D$;

- обчислення значення цільової функції в кожній точці $D^{c}$ і визначення серед них оптимального (це здійснюється за допомогою сучасних пакетів прикладних програм на персональних комп'ютерах);

- $\quad$ відшукання відповідного оптимального плану (або планів), тобто координат точок максимуму чи мінімуму за відомим значенням цільової функції. 
Як бачимо, за методом НЦС перебираються всі точки з цілими координатами, тобто він є методом повного перебору, або методом «грубої сили» (від англ. brute force). Він вичерпує усі можливі варіанти. У методі НЦС під «вичерпуванням» слід розуміти перебір усіх цілих точок області $D^{c}$. Оптимальний план $X^{*}$ (або плани) цільової функції відшукується за оптимумом числового масиву ії значень.

За відомими методами лінійного програмування знаходили оптимальні плани послабленої ЗЦП, а за ним і сам оптимум (із подальшим просуванням до цілочислового плану). У методі НЦС навпаки: за оптимальним значенням цільової функції знаходяться відповідні - оптимальні - допустимі плани.

Розглянемо простенький приклад розв’язання ЗЦП в $\mathbf{Z}_{+}^{2}$.

Постановка задачі:

$z=9 x+8 y \rightarrow \max ;$

$\left\{\begin{array}{l}4 x+28 y \leq 77 \\ 36 x+28 y \leq 189\end{array}\right.$

$x \geq 0, y \geq 0 ; x \in \mathbf{Z}, y \in \mathbf{Z}$.

Область усіх допустимих планів задачі $D$, i область усіх іï цілих точок $D^{c}$ зображені на Рисунку 4.

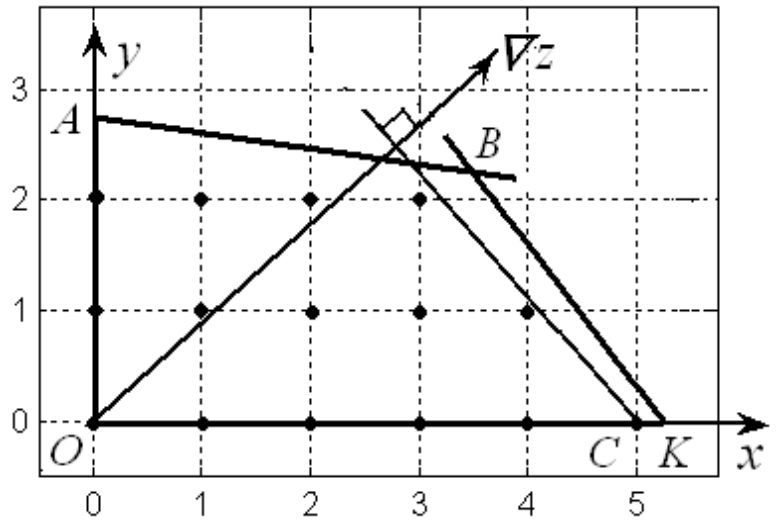

Рисунок 4. Графічне зображення області допустимих значень і цілочислової сітки

Розв'язання лінійної ЗЦП здійснювалося в середовищі ППП MatLab [7]. На множині $D^{c}$ максимальне значення функції цілі: $z=45$, визначає цілочисловий план: $X_{\max }(5,0)$. Оптимальний план послабленої ЗЦП визначається точкою $B(3,5 ; 2,25)$ (див. Рисунок 4$)$.

Таким чином, застосовуючи НЦС, ми отримали цілочисловий оптимум, обминаючи розв’язування послабленої ЗЦП.

«Прокляття вимірності», тобто проблема експоненціального зростання кількості даних у разі багатовимірних просторів, не є для методу НЦС перешкодою. Справа в тому, що не будь-який алгоритм прямого перебору є експоненційним. Установлено [6], що алгоритм пошуку найменшого (найбільшого) елемента в числовому масиві, незважаючи на його перебірний характер, є лінійним, а не експоненційним, оскільки такий алгоритм детермінований.

Якщо в цьому сенсі порівнювати методи відтинання і комбінаторні методи розв’язання ЗЦП з методом НЦС, то перевага на боці запропонованого методу, бо розв’язати нову задачу для знаходження чергової цілої точки значно складніше, ніж обчислити значення цільової функції.

Серед сучасних проблем управління підприємствами $є$ відсутність економіко-математичних моделей нелінійних процесів. Добре розроблені лінійні моделі опису економічних процесів $є$ неефективними для постановки і розв'язання багатьох важливих задач, пов’язаних з нелінійними процесами в економіці. Таке становище спостерігається і відносно нелінійних динамічних процесів взагалі.

На відміну від цього, метод НЦС можна впровадити, причому без принципових змін, у нелінійні задачі математичного програмування. Крім того, його з успіхом можна застосовувати в інших галузях знань прикладного характеру, а саме: кристалографія, оптимальний розкрій матеріалів, теорія алгоритмів, теорія чисел тощо. 
Переваги методу НЦС над існуючими точними методами цілочислового математичного програмування такі:

- на функцію цілі накладається тільки одне обмеження: вона повинна бути обмеженою в розглядуваній області; проте довільною 3 точки зору математичного аналізу: неперервна і диференційовна; не неперервна і недиференційовна;

- областю допустимих значень може бути будь-яка замкнена однозв'язна чи многозв'язна область 3 межею з кусків неперервних кривих чи поверхонь.

«Прокляття вимірності», пов’язане з експоненціальним зростанням кількості даних, можливо побороти, запроваджуючи регіональний метод НЦС:

- область допустимих планів розбивають на підобласті (регіони);

- на кожному регіоні розв’язують поставлену задачу;

- серед регіональних оптимумів знаходять оптимальне значення функції цілі на всій заданій області допустимих планів;

• оптимальний план (або плани) знаходять за відповідним значенням функції цілі.

Для зменшення часових витрат на розв’язання ЗЦП регіональним методом НЦС знаходження оптимумів на регіонах доцільно здійснювати одночасно на декількох комп’ютерах.

Значною перевагою методу НЦС є те, що відкривається можливість розв’язувати задачі суто дискретного програмування, а не його окремого випадку - цілочислового математичного програмування.

Розроблені конструктивні засоби побудови цілочислових сіток дають можливість побудувати сітку 3 вузлами не тільки на координатних лініях, а й занумерувати точки з дробовими координатами. Для цього достатньо координатні функції помножити на сталу, меншу одиниці.

Такий підхід реалізовний не тільки у двовимірному чи тривимірному просторі, а й у просторах більшої вимірності.

Можна запровадити також локальний метод НЦС, який передбачає дослідження функції цілі в околі оптимального цілочислового плану, якщо дослідника цікавлять ії значення за умови нецілих координат допустимих змінних, звісно, із заданою точністю. Інакше кажучи, локальний метод НЦС дає змогу повернутися до розв’язання послабленої ЗЦП.

Проілюструємо прикладами нелінійну оптимізацію в задачах цілочислового математичного програмування (практична значущість можливостей щодо використання запропонованого підходу до вирішення конкретних задач полягає в тому, що метод НЦС застосовний за умов будь-якої обмеженої області допустимих планів і будь-якої цільової функції).

Задача 1. (геометричне програмування).

\section{Постановка задачі:}

$U=40 x^{-1} y^{-1 / 2} z^{-1}+20 x z+20 x y z \rightarrow \min ;$

$1 / 3 x^{-2} y^{-2}+4 / 3 y^{1 / 2} z^{-1} \leq 1$;

$x>0, y>0, z>0$ - цілі числа.
На етапі вирішення завдань оптимізаційного характеру (загального обсягу виробництва, максимізації прибутку від виробничої діяльності) геометричне програмування (ГП) застосовують коли йдеться про знаходження оптимальних розмірів тривимірних виробів (тіл).

Розміри (конструктивні характеристики, вартісні параметри) виробу повинні бути вибрані таким чином, щоб його вартість була мінімальною. 


\section{Розв'язання.}

Накладання цілочислового бруса на область, яка визначається обмеженнями, дозволяє розв'язати задачу геометричного програмування без переходу до двоїстої задачі і без розв'язування системи нелінійних алгебраїчних рівнянь [2].

На Рисунку 5 зображено відповідний брус; квадратиком відмічено точку мінімуму:

$x_{\min }=1, y_{\min }=1, z_{\min }=2 ; U_{\min }=100$.

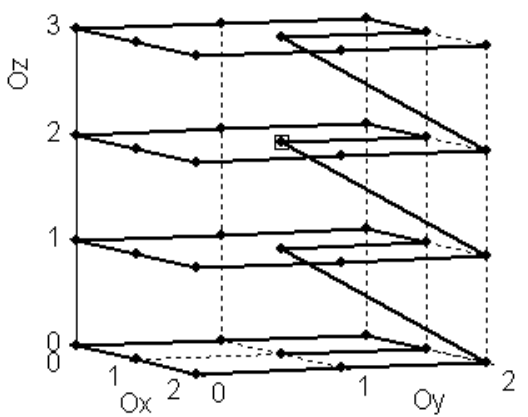

Рисунок 5. Зображення бруса $\operatorname{Bar}(1,4)$

Задача 2. (дробово-лінійне програмування).

\section{Постановка задачі:}

$U=(-2 x-y+z) /(x+3 y+5 z) \rightarrow \min ;$

$\left\{\begin{array}{l}6 x-3 y+z \leq 12 \\ 7 x-y+2 z \leq 12 \\ -4 x+2 y-z \geq 1\end{array}\right.$

$x \geq 0, y \geq 0, z \geq 0$ - цілі числа.
В задачах прикладної економіки цілочислове дробово-лінійне програмування застосовують у плануванні та управлінні виробництва (на мікроекономічному рівні) для визначення оптимальних обсягів виробництва чи витрат для його досягнення. Цілочислові характеристики продукції обумовлені вимогами типу (масштабів) виробництва, особливостей технології виробництва, обладнання.

Розв’язання. Накладання цілочислового бруса на область, яка визначається обмеженнями, не потребує зведення шляхом заміни змінних задачі дробово-лінійного програмування до ЗЛП.

На Рисунку 6 зображено відповідний брус, де квадратиком відмічено точку мінімуму:

$$
\begin{aligned}
& x_{\text {min }}=2, y_{\text {min }}=5, z_{\text {min }}=0 ; \\
& U_{\text {min }}=-9 / 17 .
\end{aligned}
$$

Нумерація основи бруса здійснювалася за схемою, наведеною у роботі Серпінського [12], де показано, власне, тільки саму схему, без опису в аналітичному вигляді.

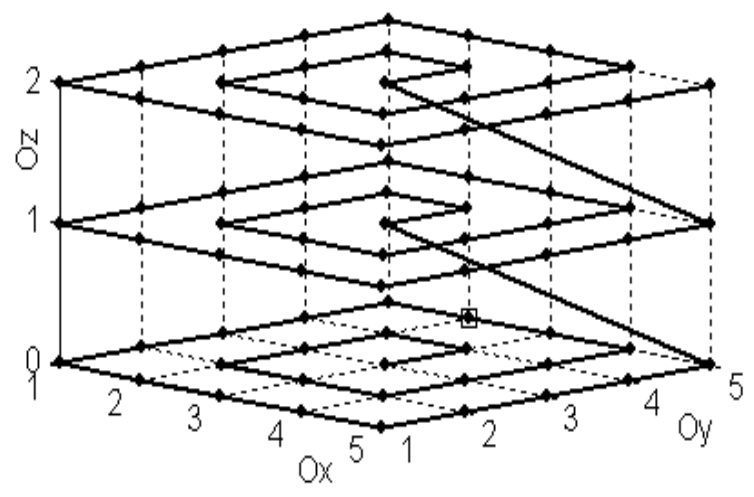

Рисунок 6. Зображення бруса $\operatorname{Bar}(2,3)$ 
Задача 3 (нелінійне програмування з неопуклою областю).

\section{Постановка задачі:}

$$
\begin{aligned}
& U=x^{2}+y^{2}+z^{3}-x y-5 x+6 z \rightarrow \\
& \rightarrow \max (\min ) \\
& \left\{\begin{array}{l}
z-2,25+\sqrt{0,5625-(x-1,5)^{2}-(y-1,5)^{2}} \leq 0 \\
z-(x-1,5)^{2}-(y-1,5)^{2} \geq 0 \\
z-2,25 \leq 0 \\
x \geq 0, y \geq 0, \quad z \geq 0 ; x \in \mathbf{Z}, y \in \mathbf{Z}, z \in \mathbf{Z} .
\end{array}\right.
\end{aligned}
$$

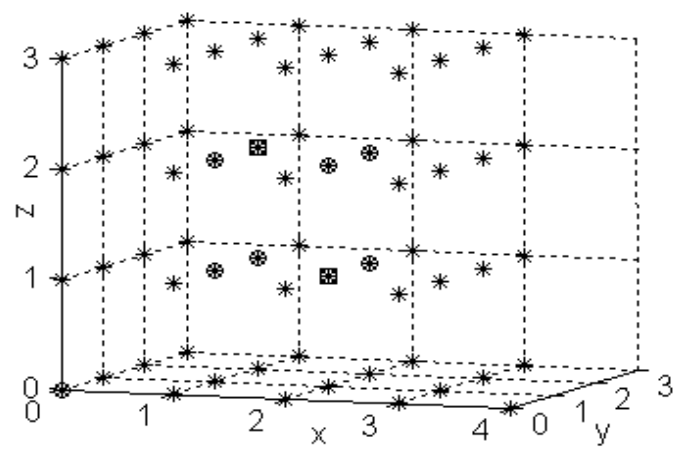

Зауваження. На сьогодні, на жаль, економікоматематичні моделі з нелінійною цільовою функцією i довільними нелінійними обмеженнями ще не

Рисунок 7. Накладання цілочислової сітки

Розв'язання. Областю $D \in$ тіло, обмежене нижньою півсферою радіусом 0,75 з центром у точці $(1,5 ; 1,5 ; 2,25)$, круговим параболоїдом із віссю симетрії $x=1,5 ; y=1,5 ; z=t, t \in(-\infty,+\infty)$, і площиною $z=2,25$. На Рисунку 7 зображено: цілі точки 3-куба (*), цілі точки (०) в області обмежень (кружки накладені на зірочки); квадратиками відмічено оптимальні плани-точки $X_{\max }=(1,2,2)$ і $X_{\min }=(2,1,1)$. Оптимуми функції цілі: $U_{\max }=18, U_{\min }=0$.

Зауважимо, що ця задача не піддається розв'язанню іншими точними методами математичного програмування. Функція цілі диференційовна, але перше і друге обмеження нелінійні. Ця обставина унеможливлює застосування існуючих методів оптимізації.

У наступній задачі функція цілі нелінійна і недиференційовна, а обмеження містять квадратичну ірраціональність.

Задача 4 (дробово-нелінійне програмування з неопуклою областю).

\section{Постановка задачі:}

$U=\frac{x^{3} y-y^{2} \ln (1+z)+\operatorname{arctg} z}{e^{x}(1+|\cos z|)} \rightarrow \max (\min ) ;$

$$
\left\{\begin{array}{l}
z-3 \leq 0 \\
z-\sqrt{(x-1,5)^{2}+(y-1,5)^{2}} \geq 0 \\
z-3+\sqrt{0,25-(x-1,5)^{2}-(y-1,5)^{2}} \leq 0 \\
x \geq 0, y \geq 0, z \geq 0 ; x \in \mathbf{Z}, y \in \mathbf{Z}, z \in \mathbf{Z} .
\end{array} ;\right.
$$

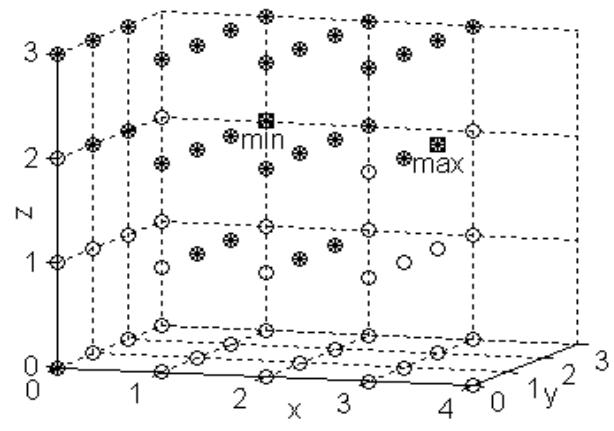

Рисунок 8. Накладання цілочислової сітки

Розв’язання. Функція цілі раціонально залежна від основних елементарних функцій і недиференційовна (з огляду на наявність модуля) у точках із $z=\pi / 2$. 
На Рисунку 8 зображено: цілі точки 3-куба $\left({ }^{\circ}\right)$, цілі точки $(*)$ в області обмежень (зірочки накладені на кружки); квадратиками відмічено оптимальні плани-точки $X_{\max }=(3,2,2)$ і $X_{\min }==(1,3,2)$. Відповідні значення функції цілі: $U_{\max }=1483 / 306, U_{\min }=-643 / 1164$.

Особливої уваги заслуговує задача оптимізації широко відомої [1] виробничої функції Кобба - Дугласа (1928): $Z=a_{0} x^{\alpha} y^{\beta}$, де $x, y$ - обсяг використаної праці і капіталу, відповідно; $a_{0}, \alpha, \beta$ - сталі, що характеризують технологію виробництва.

У більш загальному випадку, у разі змінної технології виробництва, величини $\alpha, \beta \in$ відповідно змінними величинами.

Задача 5 (модель Кобба - Дугласа).

\section{Постановка задачі:}

$Z=3 \sqrt{x \cdot y} \rightarrow \max Z$

$\left\{\begin{array}{l}x+y \geq 3,0 \leq x \leq 10 \\ 2 x-y \leq 6,0 \leq y \leq 10\end{array} ; x \in \mathbf{Z}, y \in \mathbf{Z}\right.$.

Розв'язання. За методом НЦС $D^{c}$ - прямокутна цілочислова сітка. Відповідна область зображена на Рисунку 9; квадратиком відмічено оптимальний план:

$x_{\text {max }}=7, y_{\text {max }}=9, Z_{\text {max }} \approx 19,44$.

Зауваження: сталі обмежень виражені в умовних одиницях.

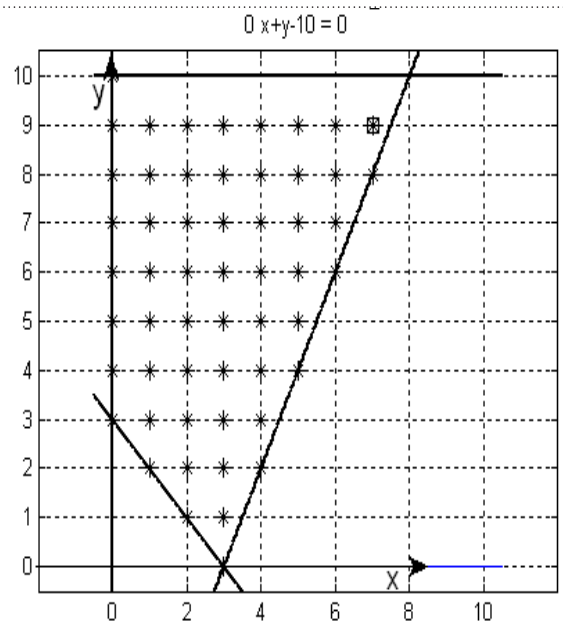

Рисунок 9. Накладання цілочислової сітки

Аналіз тенденцій розвитку світової економіки, зміна структури (питомої ваги окремих галузей) та їх параметрів в загальних обсягах свідчить про бурхливий розвиток електронного бізнесу. Це вимагає необхідності своєчасного вирішення проблеми i, разом із тим, відповідності параметрів обчислювальної техніки, що одночасно підтверджує перспективи методу НЦС як точного методу «грубої сили», за яким $\epsilon$ майбутнє. Найбільш доцільним, на нашу думку, є застосування даного методу на етапі економічного прогнозування очікуваних результатів діяльності суб'єктів господарювання саме у періоди економічних криз (етапу після кризового відновлення економіки), в умовах наявності нестабільних, невизначених параметрів впливу зовнішнього середовища на внутрішні економічні процеси.

\section{ВИСНОВКИ}

Існуючі алгоритми в межах класичних математичних задач дозволяють фахівцям 3 управління підприємством вирішити багато інших економічних завдань в практичному секторі економіки, які спрямовані на усунення першопричин тих чи інших проблем.

Досягнення мети дослідження дозволило автору запропонувати уніфікований метод, який не потребує розв'язання послабленої задачі математичного програмування, тобто без урахування дискретності змінних, а також забезпечує можливості для будь-якої цільової функції, обмеженої в довільній області допустимих планів, знайти екстремальне значення. 
Наукова новизна отриманих результатів дослідження полягає у впровадженні в цілочислове математичне програмування аналітичного опису дискретної, зокрема цілочислової множини точок двовимірного простору (площини) та тривимірного простору, і загалом - багатовимірного простору. Особливості практичного застосування результатів дослідження обумовлені проблемою управління підприємствами в умовах моделювання нелінійних процесів в економіці, як і взагалі врахування нелінійних динамічних процесів.

За допомогою методу НЦС відкриваються можливості оптимізувати будь-яку цільову функцію, обмежену в заданій області - лінійну чи нелінійну, неперервну чи розривну, диференційовну чи не диференційовну, з будь-якою замкненою областю допустимих значень, у тому числі - многозв’язною, 3 межами із кусків неперервних кривих чи поверхонь. Метод НЦС дозволяє розв'язувати задачі саме дискретного, а не тільки цілочислового програмування як його окремого випадку.

Вимоги щодо змінних величин бути дискретними чи цілочисловими (як частинного випадку дискретності) притаманні багатьом практичним задачам: вибір послідовності виробничих процесів, календарне планування роботи підприємства, планування та забезпечення матеріально-технічного постачання, розміщення підприємств, розподіл капіталовкладень, планування використання обладнання тощо.

Запропонований в роботі підхід до розв'язання оптимізаційних задач прикладного характеру є більш ефективним за рахунок меншої трудомісткості та терміну розв’язування.

На перспективу, за умови розроблення відповідного програмного забезпечення, вважається за доцільне розв'язання не модельних, а реальних задач економічного змісту. Висловлюємо впевненість також, що метод НЦС стане активно використовуватись для побудови нових економіко-математичних моделей.

\section{СПИСОК ЛІТЕРАТУРИ}

1. Cobb, C. W., \& Douglas, P. H. (1928). A theory of production. American Economic Review, 18, 139-165.

2. Daffin, R., Piterson, E., \& Zener, K. (1972). Геометрическое программирование [Geometricheskoe programirovanie] (312 p.). Moscow: Mir.

3. Ershov, Yu. L. (1977). Теория нумераций [Teoriya numertsiy] (416 p.). Moscow: Nauka.

4. Gabasov, R., Kirillova, F. M., Alsevich, A. I., Kalinin, V. V., Krakhotko, V. V. \& Pavlenok, N. S. (2011). Memodы onmuмuзаuиu [Metody optimizatsii] (474 p.). Minsk: Chetyre chetverti.

5. Korbut, A. A., \& Finкеlshteyn, Yu. Yu. (1969). Дискретное программирование [Diskretnoye programmirovaniye (Seriya: «Екопотікомаtematichesкауa biblioteка»)] (368 p.). Moscow: Nauka.

6. Kormen, T., Leizerson, Ts., \& Ryvecst, R. (2001). Алгоритмы: построение и анализ [Alhorytmy: postroenye i analiz] (960 p.). Moscow: MTSNMO.

7. Kurbatova, E. A. (2006). MATLAB 7. Самоучитель [MATLAB 7. Samouchitel] (256 p.). Moscow: Izdatelsкiy dom «Vilyams».

8. Rvachev, V. L. (1982). Теория R-функций и некоторые ее приложения [Tеогіya R-fuпкtsy i пекоtorye eye prilozheniya] (552р.). Kiev: Nаuкоva duмка.

9. Senchukov, V. F. (2014). Цілочислові сітки на площині в задачах дискретної оптимізації [Tsilochislovi sitky na ploshchyni v zadachakh dyskretnoi optymizatsii]. Ekonomika rozvytku, 3(71), 107-112.

10. Senchukov, V. F. (2015). Метод накладання цілочислових сіток в економічних задачах дискретної оптимізації [Metod nakladannia tsilochyslovykh sitoк v ekonomichnykh zadachakh dyskretnoi optymizatsii]. In Materialy Mizhnarodnoi naukovo-praktychnoi konferentsii «Suchasni problemy upravlinnia pidpryiemstvamy: teoriia ta praktyka», Kharkiv, 26-27 bereznia 2015 (pp. 241-244).

11. Senchukov, V. F. (2015). Просторові цілочислові сітки в задачах дискретної оптимізації [Prostorovi tsilochislovi sitky v zadachakh dyskretnoi optyminizatsii]. Upravlinnia rozvytkom, 2(180), 116-123.

12. Serpinskiy, V. (1961). Сто простых, но одновременно трудных вопросов арифметики [Sto prostykh i odnovremenno trudnykh voprosov arifmetiki] (76 p.). Moscow: Uchpedgiz. 